\title{
Physicochemical Changes of Commercial "Kounou" During Short Term Storage at Room and Refrigerated Temperatures
}

\author{
James Ronald Bayoï, Bakari Daoudou, Simon Ndegoue Vecha, Djoulde Darman Roger, François- \\ Xavier Etoa
}

\section{ABSTRACT}

Fermented cereal-based drinks as "kounou" are among the most popular indigenous beverages in Northern Cameroon. Because they are made in a primitive way, they are ready to be served while still actively fermenting. Therefore, some physicochemical properties of "kounou" were tested in the current study during 4 days of storage at room and refrigerated temperatures. Samples of "kondourkou" a sub type of "kounou" were purchased from local producers located in the Far North region of Cameroon. During storage at $28 \pm 2^{\circ} \mathrm{C}$ and $4 \pm 1^{\circ} \mathrm{C}$, total sugars, pH, total acidity, alcohol content, total soluble solids, dry matter, total dissolved solids, and conductivity of samples were measured in triplicate using standards procedures. The results showed that $\mathrm{pH}$ decreased from 3.34 to 3.16, and 3.65 to 3.4 after storage at room and refrigerated temperatures, respectively. The decrease in total sugar $(30.3 \%-12.1 \%)$ and soluble solids $\left(7.26-4.89^{\circ} \mathrm{Brix}\right)$, as well as increase in titratable acidity $(0.26 \%-0.36 \%)$ were significant for samples stored at ambient temperature. While no significant changes in all these parameters were revealed for samples stored at cold conditions $\left(54.8 \%-37.9 \% ; 8.79-8.13{ }^{\circ}\right.$ Brix and $0.18-0.25 \%$, respectively). Dry matter and total dissolved solids were lower in samples stored at room temperature (from $10.3-11.2 \%$ and $841.9-1002 \mathrm{mg} / \mathrm{L}$, respectively) than those kept under refrigeration (from 12.15 to $12.5 \%$ and 1061.2-1231.7 mg/L, respectively). Alcohol content and conductivity were respectively in the range of 3.5-2.35\% and $1692.4-2012.5 \mathrm{mg} / \mathrm{L}$ for samples stored at room temperature, and $3.18-3.37 \%$ and $1692.4-2205 \mathrm{mg} / \mathrm{L}$ for those kept under refrigeration. Principal component analysis revealed that samples stored under refrigeration were structured in two sub-cluster, the first formed by those stored for 1 and 2 days and the second including those kept for 3 and 4 days. While samples left at room temperature were separated into three sub groups, those stored for a day, 2 and 3 days, and 4 days. Finally, it would be appropriate to consume refrigerated "kounou" as well as commercialize and/or store it under refrigeration.

Keywords: Indigenous beverages, kounou, storage, physicochemical properties, quality, temperature.

Published Online: January 24, 2022

ISSN: $2684-5199$

DOI: $10.24018 /$ ejbio.2022.3.1.262

\section{J. R. Bayoï*}

Department of Biological Sciences, University of Maroua, Cameroon.

(e-mail : jabar982002@gmail.com)

B. Daoudou

Department of Biological Sciences, University of Maroua, Cameroon.

(e-mail : bkimou3@gmail.com)

S. N. Vecha

Department of Biological Sciences, University of Maroua, Cameroon.

(e-mail : vechandosim@gmail.com)

D. D. Roger

Department of Agriculture, Livestock and by Products, National Advanced School of Engineering of Maroua, University of Maroua, Cameroon.

(e-mail : djoulde@gmail.com)

F-X. Etoa

Department of Microbiology, University of Yaoundé 1, Cameroon.

(e-mail : fxetoa@yahoo.fr)

*Corresponding Author

\section{INTRODUCTION}

Traditional fermented beverages are an important feature of many African countries' food cultures. They are socially acceptable goods for both routine and ritual consumption. Various raw resources such as fruits, roots, tubers, seeds and grains are used to make a variety of African traditional beverages (Ezekiel et al., 2018).

Traditional cereal-based fermented beverages, particularly those made from maize (Zea mays L.) and sorghum (Sorghum bicolour L. Moench), are among the most popular and commonly consumed traditional drinks in Sub-Saharan Africa and other sub-tropical countries (Blandino et al., 2003). These cereal grains, as well as finger (Eleusine coracana) and pearl millet (Pennisetum glaucum L.) are used to make a diversity of traditional alcoholic and non-alcoholic concoctions, including Ethiopian "cheka" (Binitu et al., 2018), Tanzanian "togwa" (Mugula et al., 2003), Ivorian "tchapalo" (Egue et al., 2018), Beninese "gowé" (Fellows et al., 2014) and "mawe" (Hounhouigan, 1994), Ghanaian "pito" (Ebbah et al., 2015), Ugandan "bushera" (Muyanja et al., 2003), "kwete" (Muyanja \& Namugumya, 2009), "malwa" (Muyanja et al., 2010), Zimbabwean "mahewu" (Pswarayi \& Gänzle, 2019), Nigerian "ogi” (Praise et al., 2020) and Cameroonian red "té" and white "mpedli" Bayoï et al., 2016; Ronald \& Roger, 2017). Traditional beverages are extensively drunk and preferred to industrial drinks by individuals from low-income areas due to cheaper producing costs, perceived better nutritional value, and availability of 
these beverages in local markets (Ezekiel et al., 2015). Indeed, these traditional fermented concoctions are regarded as food because they fulfil hunger and as drink because they alleviate thirst (Fadahunsi et al., 2013).

In Northern Cameroon, another variety of these traditional drinks called "kounou" is produced. It is mostly made from sorghum grain; however, it is occasionally blended with maize and millet grains (Mathieu et al., 2021). Sorghum contains many nutrients, including sugar, copper, fiber, iron, isoleucine, manganese, magnesium, phosphorus, leucine, protein, tryptophan, vitamin B6, valine, vitamin B1, vitamin B3 and selenium which account for $106.47 \%, 60.56 \%, 48 \%$, $80.63 \%, 49.095 \%, 134 \%, 75.48 \%, 79.295,77.46 \%, 40.78 \%$, $54.09 \%, 65.64 \%, 50.99 \%, 53.08 \%, 44.26 \%, 42.55 \%$ of the recommended daily value (Praise et al., 2020). "Kounou", indigenous sorghum concoction, is made through a series of processes that include washing, steeping and wet milling of grains, cooking, ambient cooling, mixing with malted flour or sweet potatoes flour, spontaneous fermentation, the addition of sugar and sometimes supplementation of optional ingredients as nuts and spices. A comparable cereal-based fermented beverage is manufactured in Northern Nigeria; however, it is occasionally characterized in the literature under other names: "kunu" (Ezekiel et al., 2019), "kunuzaki" (Abiodun et al., 2017), and "kunun-zaki" (Duche \& Abdulganiu, 2020). "Kounou" is usually a non-alcoholic cereal beverage, but when fermentation extents some varieties can be alcoholic. Indeed, three varieties of "kounou" are defined based on the level of fermentation: short-term fermented "kounou foulbé," moderate-term fermented "kondourkou" and long-term fermented "kass." According to customer preferences and manufacturers, "kondourkou" is the most appreciated "kounou" subtype because of its excellent sour-sweet taste (Bayoï et al., 2021). In the poorest parts of Northern Cameroon, local women make this traditional drink for sale to support their family. After processing, "kounou" can be served immediately or chilled.

Like many fermented cereal-based drinks, "kounou" has a limited shelf life, which obliges its daily production and restricts its large-scale production. To increase the quality and shelf life of such a product, it is necessary to examine the physicochemical changes that occur during storage due to microbial activity that persists after manufacturing. To date, no published data on changes occurring within the initial days following production as well as the quality of this indigenous cereal beverage is available. Moreover, given that the impact of storage on each locally made beverage differs, and the delay during which the drinks lose their qualities changes from one drink to another; it is necessary to determine the most suitable way of conservation, whether ambient or refrigerated, to limit the instability of homemade drinks. Therefore, this study aimed to address these gaps by tracing the physicochemical changes of marketed "kounou" at room and low-temperature storage, opening the path for its quality to be improved.

\section{MATERIALS AND METHODS}

\section{A. Samples Collection and Storage}

The commercial fresh samples of "kounou" were purchased at the "central" market of the city of Maroua (Diamaré division, Far North region of Cameroon). The samples were immediately iced and transported to the laboratory within an hour after being aseptically collected. The samples collected in twenty-four (24) sterile bottles of $100 \mathrm{~mL}$ were separated into two groups. Twelve samples were kept at room temperature $\left(28 \pm 2^{\circ} \mathrm{C}\right)$ for four days, while the remaining twelve were stored in the refrigerator at $4^{\circ} \mathrm{C}$ for the same length of time. In each group, three bottles were taken out daily for analysis during the storage period. Therefore, all analyses were carried out in triplicate.

\section{B. Preparation of Samples before Analysis}

Before analysis, the samples were centrifuged at 1500xg for 5 minutes and supernatants were filtered through filter paper (Whatman \#1) as well as a membrane filter $(0.62 \mathrm{~m}$ diameter). The collected filtrates were tested for the assessment of the evolution of physicochemical parameters such as $\mathrm{pH}$, total acidity, alcohol content, electrical conductivity, total dissolved and soluble solids, dry matter and total sugar during the storage.

\section{Physicochemical Analysis}

As indicated by Blessed et al. (2017), the $\mathrm{pH}$ of the stored samples was evaluated using a calibrated portable $\mathrm{pH}$ meter (Eco Testr, Singapore). The total titratable acidity of the samples was evaluated using the alkali-potentiometric technique and sodium hydroxide solution $(0.1 \mathrm{~N})$ was employed as a titrant (Ghosh et al., 2014). After distillation of sample rendered alkaline by a suspension of calcium hydroxide, the total alcohol content was determined using a spectrophotometric micro method (Magrí et al., 1997). The total soluble solids (TSS) were measured directly using a portable ATC refractometer (RHB 90, Shenzhen, China), while both the electrical conductivity and total dissolved solids (TDS) were measured using a multifunctional portable conductivity meter (e-1 TDS \& EC) according to the method described by Bayoï et al. (2016). The dry matter content was determined using the method proposed by Yeğin and Üren (2008), which involved desiccating of the sample at $105^{\circ} \mathrm{C}$ until the constant weight was reached. Total sugar was determined using the phenol-sulfuric improved method as described by Debebe et al. (2018). The optical density (OD) values recorded at $490 \mathrm{~nm}$ wavelength were measured using a UV-Visible spectrophotometer (Jenway 7305, Bibby Scientific, Group HQ, Staffordshire, UK). From a calibration curve $\left(\mathrm{y}=5.8243 \mathrm{x} ; \mathrm{R}^{2}=0.9997\right)$ obtained by different glucose solution concentrations $(0-10 \mathrm{~g} / \mathrm{mL})$, the recorded OD values were used to determine total sugar as g of glucose equivalent (GE) per $100 \mathrm{~mL}(\mathrm{gGE} / 100 \mathrm{~mL})$ equivalent to percent of glucose equivalent $(\% \mathrm{GE})$.

\section{Statistical Analysis}

The raw data were compiled in an Excel database and the results represented as mean \pm standard deviation. To compare means, one-way analysis of variance (ANOVA) was performed using Statgraphics Centurion software. Tukey's Honest Significant Differences (HSD) test was used to 
evaluate mean differences, which were found significant at $\mathrm{p}<0.05$. Pearson's coefficient (r) was used to achieve correlations between the parameters studied, with three significance levels at $p<0.05, p<0.01$, and $p<0.001$. Using principal component analysis (PCA), it was feasible to integrate all of the parameters that were examined. This analysis was carried out using the XLSTAT program. By this analysis approach and based on the variables' correlation, the measured variables were grouped into new variables named components or factors. The principal component analysis has also been used to compare "kounou" samples from different storage conditions.

\section{RESULTS AND DISCUSSION}

\section{A. Changes in $p H$}

Changes in $\mathrm{pH}$ of "kounou" samples during storage at different conditions are illustrated in Fig. 1. The initial $\mathrm{pH}$ values were 3.34 and 3.65 for the samples stored for a day at room and refrigerated temperatures, respectively. At room temperature, decrease in $\mathrm{pH}$ values has been noticed at the second (3.23) and fourth (3.16) day of the storage. At low temperature, the same decrease has been revealed after the third (3.48) and fourth (3.4) days of the storage. The decrease in $\mathrm{pH}$ at both conditions was not significant $(\mathrm{p}>0.05)$. Attchelouwa et al. (2017) found similar results during storage of the Ivorian Coast "tchapalo" at ambient and cold temperatures. They explained this observation by suggesting that organic acids produced by microflora present during storage were not sufficient to significantly reduce $\mathrm{pH}$. Even if Attchelouwa et al. (2017) did not consider $\mathrm{pH}$ as a good stability indicator of some indigenous beverages, Tusekwa et al. (2000) therefore reported that $\mathrm{pH}$ acts as a quality control standard because it gives ideal color and taste, influences redox potential as well as microbial proliferation in the beverage. "Kounou" samples kept at room temperature had lower $\mathrm{pH}$ values than those maintained at refrigerated temperature. This might be attributed to changes in chemical and enzymatic properties in indigenous beverages caused by the storage conditions. It has also been noted a slight increase in the $\mathrm{pH}$ values at the second (3.67) and third (3.35) day of storage at cold and room temperatures. Similar facts have been reported by Tusekwa et al. (2000) with Tanzanian traditional beverages kept at ambient condition for 6 days. The $\mathrm{pH}$ values of samples stored at ambient condition significantly change only after 2 days, while the values of the samples kept at $4^{\circ} \mathrm{C}$ did not reveal a significant change in $\mathrm{pH}$ values from the first to the fourth day of storage. This means that "kounou" is more stable in terms of $\mathrm{pH}$ at low temperature than room temperature.

\section{B. Changes in Total Titratable}

Fig. 2 presents evolution of the total titratable acidity of "kounou" during the storage at ambient and cold temperature conditions. The total acidity contents in "kounou" samples were significant $(\mathrm{p}<0.05)$ and varied between $0.26 \%$ and $0.36 \%$ after the first and fourth day of storage at room temperature. While, the same parameter fluctuated from $0.18 \%$ to $0.25 \%$ for the samples stored at low temperature between the first and fourth day. A similar increase in total acidity has been reported during the storage of "burukutu' and "pito", two indigenous cereal-based beers from Nigeria and Ghana (Fadahunsi et al., 2013). The same figure indicated that samples kept at room temperature were more acidic than those stored at refrigerated temperature. These changes in the increase of the acidity might be related to the differential use of carbohydrates by microorganisms depending on temperature conditions. Temperature is one of the most significant factors affecting the growth of microorganisms in foods (Price and Sowers, 2004), therefore, microbial growth is accelerated at room temperature, while at low temperature the microbial growth declines (Huang et al., 2011). Therefore, the higher the temperature, the higher the microbial activity and fermentation of sugar (Tamang \& Nikkuni, 1998). With the result in increase of the production of organic acids (Ferone et al., 2019). This enhancement in acidity of the samples stored at ambient temperature compared to those kept at cold conditions suggests the mesophilic character of microbial flora present in "kounou" during the storage. As the increase in the acidity of the samples stored at room condition is significant $(p<0.05)$ between the first and the fourth day, while during the same period this increase has not been significant $(p>0.05)$ for the samples stored at cold temperature, it can be suggested that refrigeration prevents an increase in acidity of the locally made food during the storage (Ortolan et al., 2010).

\section{Changes in Total Sugar}

An illustration of changes in total sugar of the samples maintained both at ambient and cold temperatures is presented in Fig. 3. The decrease in total sugar of "kounou" samples fluctuated from $30.3 \%$ to $12.1 \%$ and from $54.8 \%$ to $37.9 \%$ between the first and fourth day of storage at room and refrigerated conditions, respectively. Irrespective of the storage conditions, the reduction of the total sugar in the beverage samples was found significant $(\mathrm{p}<0.05)$. This decline might be attributed to a rapid and effective use of remaining sugar available in the samples by the yeasts and bacteria present in the beverage during the storage, through fermentation (Alves-Araújo et al., 2007). At room temperature, decrease in total sugar was significant from the second $(27.6 \%)$ up to the last $(12.1 \%)$ day of storage, while no significant change $(\mathrm{p}>0.05)$ was found during the storage of "kounou" samples at low temperature. This suggests that low temperature reduces the use of sugar for microbial growth (Coffin et al., 1987), and contributes in preserving the nutritional properties of "kounou". This result coincides with findings previously reported by Maduka and Ire (2017). This has been confirmed by the fact that the sugar contents of the samples kept at low temperature were far higher than those of the samples stored at room temperature.

\section{Changes in Total Soluble Solids}

Fig. 4 shows evolution of the total soluble solids (TSS) in "kounou" samples stored both at room and refrigerated temperatures for 4 days. The TSS significantly decreased $(\mathrm{p}<0.05)$ in the ambient stored samples, while, in the refrigerated samples decrease was not statistically significant $(\mathrm{p}>0.05)$. The TSS changed from $7.26^{\circ}$ Brix to $4.98^{\circ}$ Brix and $8.78^{\circ}$ Brix to $8.13^{\circ}$ Brix between the first and fourth day 
for the samples stored at ambient and low temperatures, respectively.
Similar changes in TSS were also reported during the storage of certain African cereal-based fermented beverages (Attchelouwa et al., 2017; Tusekwa et al., 2000).

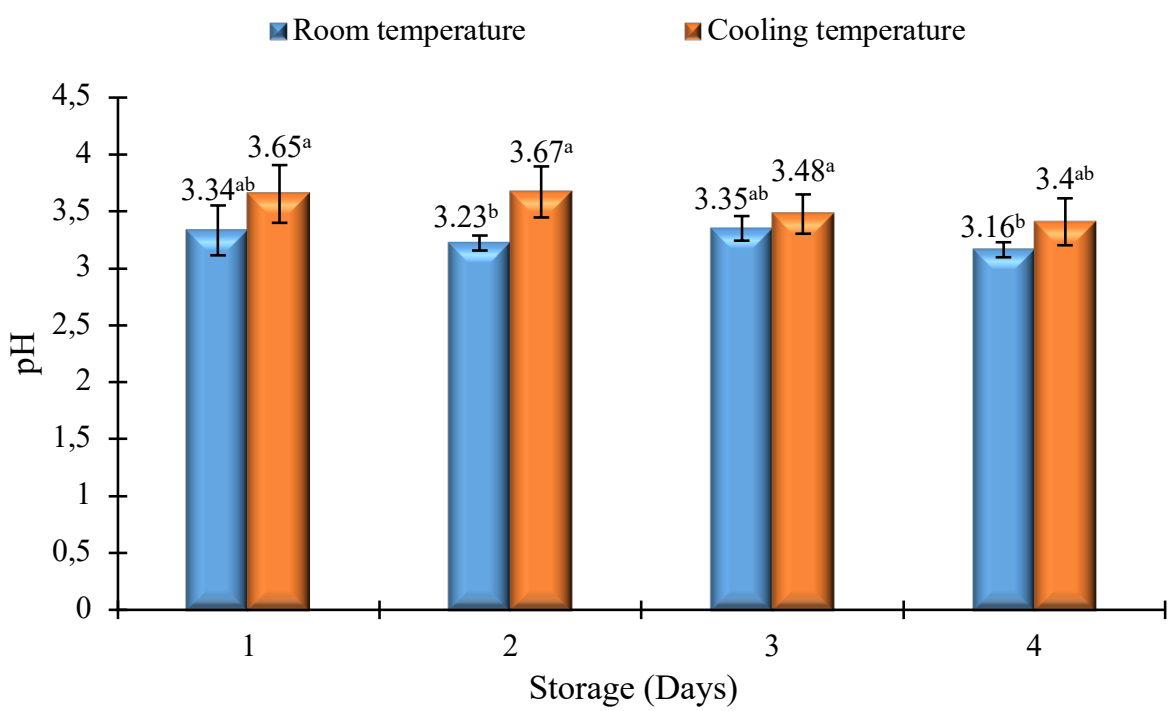

Fig. 1. Changes in $\mathrm{pH}$ of "kounou" samples stored at room $\left(28 \pm 2^{\circ} \mathrm{C}\right)$ and low $\left(4 \pm 1^{\circ} \mathrm{C}\right)$ temperature conditions. Mean values ( $\mathrm{n}=3$ repetitions) with the same superscript are not significantly different $(\mathrm{p}>0.05)$. Bars under the mean values represent standard deviations.

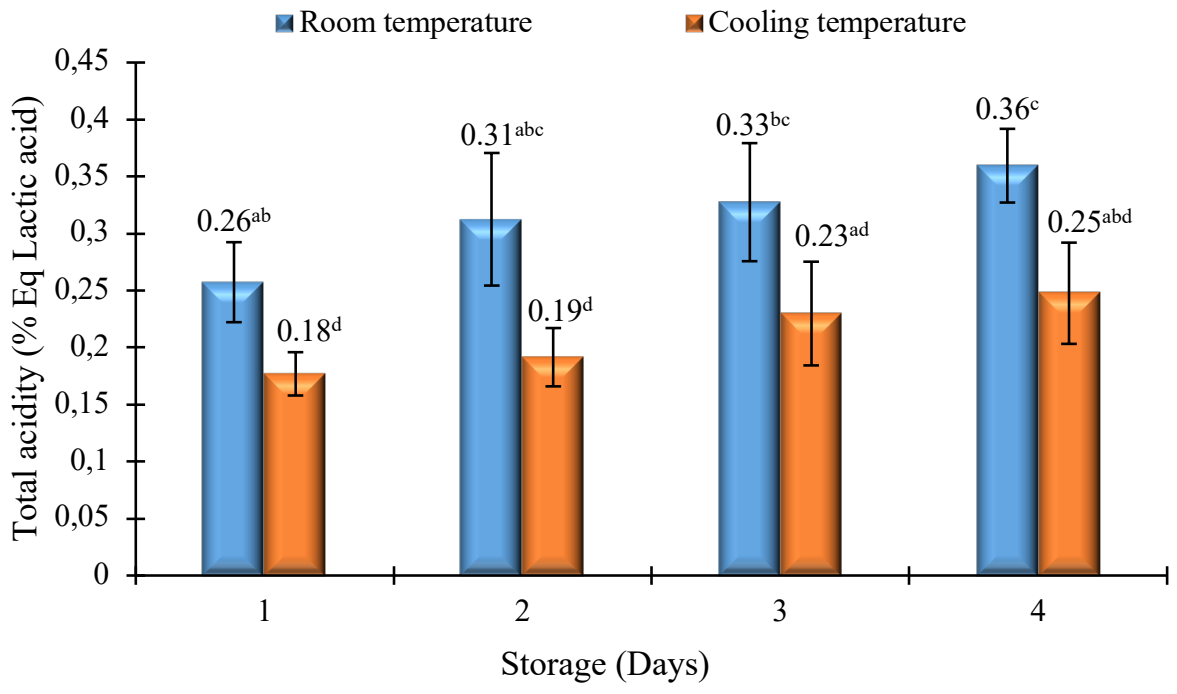

Fig. 2. Changes in total acidity of "kounou" samples stored at room $\left(28 \pm 2{ }^{\circ} \mathrm{C}\right)$ and refrigerated $\left(4 \pm 1{ }^{\circ} \mathrm{C}\right)$ temperature conditions. Mean values $(\mathrm{n}=3$ repetitions) with the same superscript are not significantly different $(\mathrm{p}>0.05)$. Bars under the mean values represent standard deviations. 


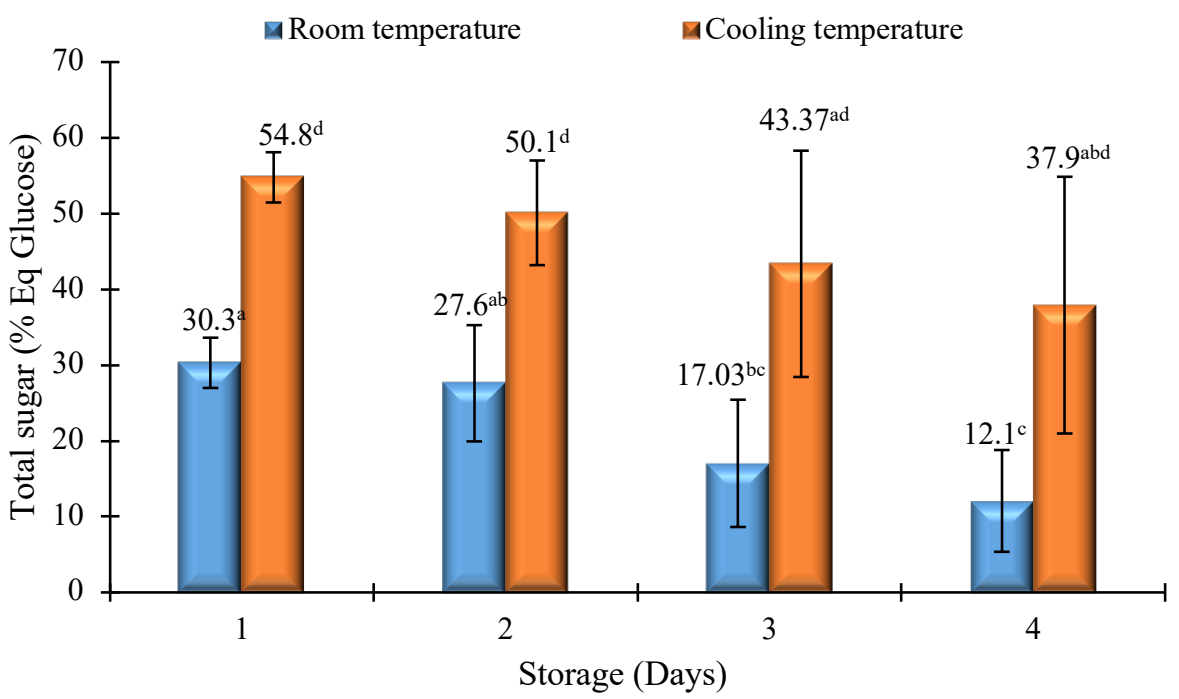

Fig. 3. Fluctuation in total sugar of "kounou" samples stored at room $\left(28 \pm 2{ }^{\circ} \mathrm{C}\right)$ and refrigerated $\left(4 \pm 1^{\circ} \mathrm{C}\right)$ temperature conditions. Mean values $(n=3$ repetitions) with the same superscript are not significantly different $(\mathrm{p}>0.05)$. Bars under the mean values represent standard deviations.

The reduction of TSS after the storage indicated that the soluble solids such as sugars were gradually degraded in a natural lacto-alcoholic fermentation process, which is the main characteristic of the indigenous African beverages consumed while they are still in an active state of fermentation (Tusekwa et al., 2000). It also revealed that total soluble solids values of the samples stored at room temperature were lower than those of the samples kept in cold condition. The same trend was reported with a similar fermented cereal-based beverage produced in Nigeria and stored at the same temperature conditions (Noah et al., 2013).

\section{E. Changes in Alcohol Content}

Evolution of alcohol content in "kounou" samples stored at different conditions for 4 days is displayed in Fig. 5. The alcohol contents were $3.5 \%$ and $3.18 \%$ for the samples stored at ambient and refrigerated conditions for a day, respectively. At room temperature, we have observed a significant decrease in the alcohol content of "kounou" samples. Fadahunsi et al. (2013) reported a similar decrease in "burukutu" and "pito" samples stored at room temperature for 7 days. This might be due to a reduction of levels of the fermentable sugars during the storage and an increase in the activity of acetic acid bacteria, which convert alcohol into acetic acid (Guillamón \& Mas, 2009). At refrigerated temperature, the alcohol content increased, but the rising was not statistically significant $(\mathrm{p}>0.05)$. Moreover, the alcohol contents of "kounou" samples stored into the refrigerator (3.32\% and $3.37 \%)$ were a little bit higher than those of the samples kept at room temperature $(2.67 \%$ and $2.35 \%)$ after 3 and 4 days. This suggests inhibition of acetification of alcohol during storage under refrigerated condition responsible for decrease of microbial activity (Zwietering et al., 1991). Indeed, thanks to alcohol dehydrogenase, many bacteria as acetic acid bacteria can convert at room temperature alcohol into acetic acid (Yakushi \& Matsushita, 2010). This organic acid is one of the key contributors for the loss of quality of most indigenous fermented cereal-based beverage as "kounou” (De Roos and De Vuyst, 2018).

\section{F. Changes in Dry Matter}

Fig. 6 illustrates evolution of dry matter in "kounou" at 4 day-period of storage. Irrespective of the storage conditions, no significant changes in dry matter of "kounou" have been observed during the storage. Moreover, "kounou" samples stored at room temperature had lower dry matter content than those refrigerated. Dry matter of the samples maintained at room temperature varied between $10.3 \%$ and $11.2 \%$, while those kept in the refrigerator showed dry matter varying from $12.15 \%$ to $13.26 \%$. Dry matter of "kounou" samples during the storage was found higher than those of fresh "dolo" (5.9\%) and "amgba" (9.5\%) samples (Aka et al., 2014) and lower than those of ready-to-be served "tchoukoutou" (18.08\%) (Kayode et al., 2011) and sorghum "gowé" (23.5\%) (Adinsi et al., 2017).

\section{G. Changes in Electrical Conductivity}

Fig. 7 represents changes in electrical conductivity of "kounou" stored at room and cold conditions for 4 days. Variation of this parameter in "kounou" samples was not significant during the storage at room and refrigerated temperatures. The lowest value of electrical conductivity was revealed for "kounou" samples stored for 3 days (1692.4 $\mu \mathrm{S} / \mathrm{cm}$ ), while the highest one was displayed by the samples stored for 4 days $(2021.5 \mu \mathrm{S} / \mathrm{cm})$ at room temperature. The lowest and highest values of electrical conductivity of "kounou" samples kept at the refrigerated temperature were of $1692.4 \mu \mathrm{S} / \mathrm{cm}$ and $2205 \mu \mathrm{S} / \mathrm{cm}$, respectively. The electrical conductivity of the samples stored at the cold temperature was higher than that of samples kept at room temperature during the first two days. On the third day, the electrical conductivity value was similar both for samples stored at room and cold temperature conditions, while on the last day, samples stored at ambient condition had higher electrical conductivity than those kept at low temperature. Even if the variation of electrical conductivity was no significant, the great fluctuation of this parameter clearly indicates that it can't be used as a suitable indicator to follow stability of indigenous beverages during the storage at ambient and lowtemperature conditions. 


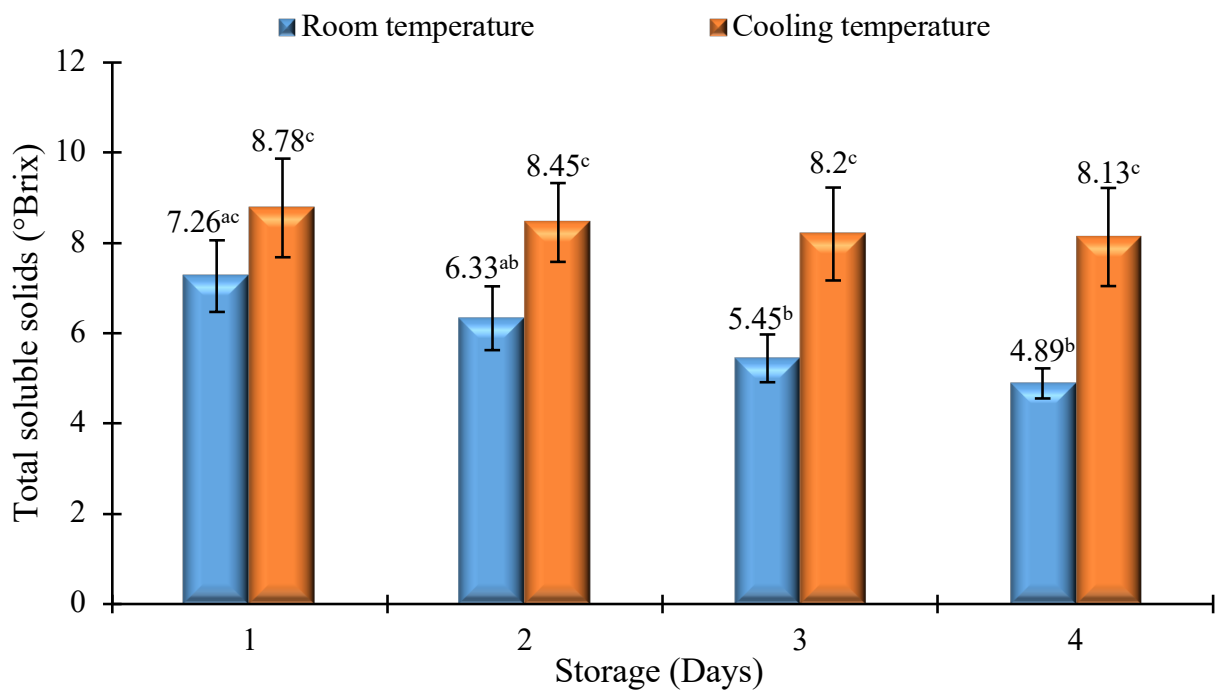

Fig. 4. Variation of total soluble solids of "kounou" samples stored at room $\left(28 \pm 2{ }^{\circ} \mathrm{C}\right)$ and refrigerated $\left(4 \pm 1{ }^{\circ} \mathrm{C}\right)$ temperature conditions for 4 days. Mean values $(n=3$ repetitions) with the same superscript are not significantly different $(\mathrm{p}>0.05)$. Bars under the mean values represent standard deviations.

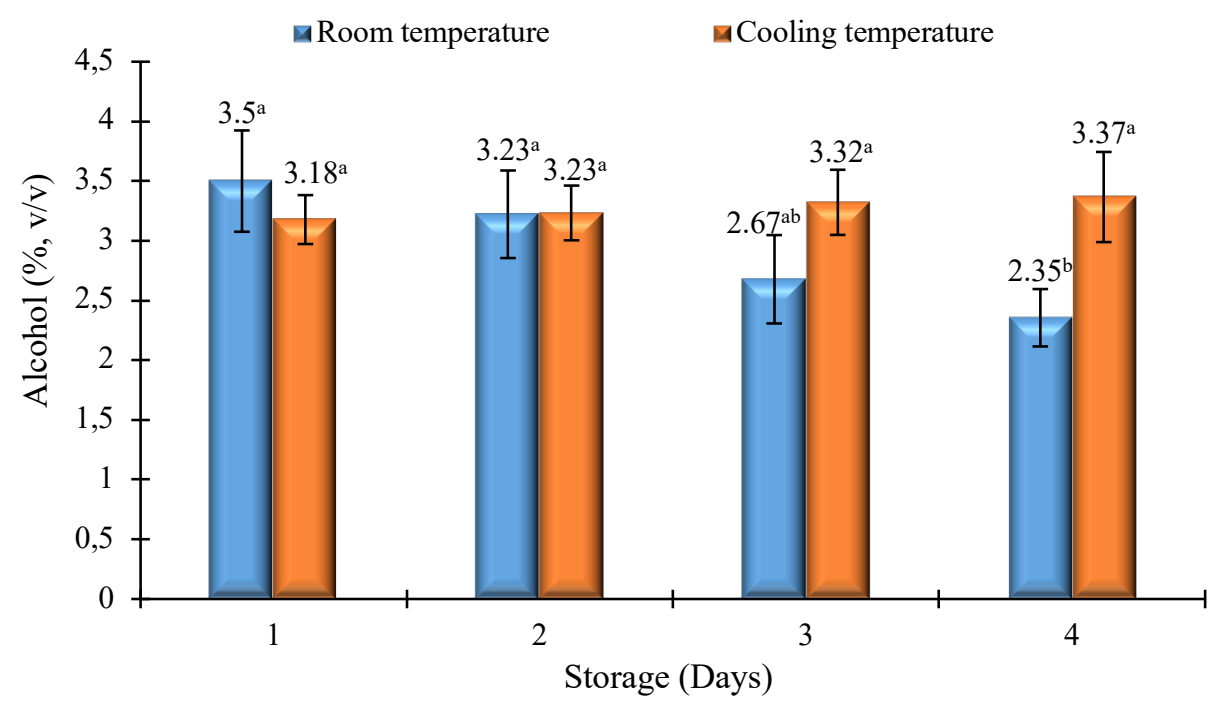

Fig. 5. Evolution of content of alcohol of "kounou" samples kept at ambient and refrigerated conditions for 4 days. Mean values ( $\mathrm{n}=3$ repetitions) with the same superscript are not significantly different $(\mathrm{p}>0.05)$. Bars under the mean values represent standard deviations.

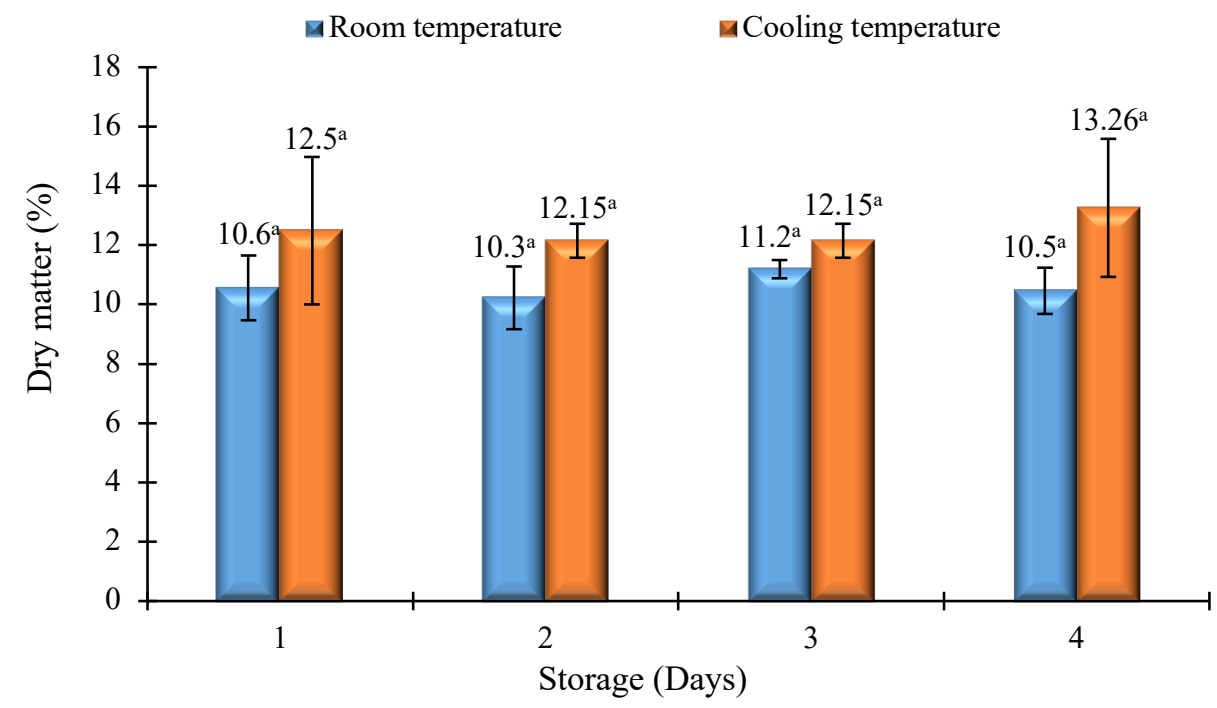

Fig. 6. Changes in dry matter of "kounou" during storage at room and refrigerator temperatures for 4 days. Mean values (n= 3 repetitions) with the same superscript are not significantly different $(\mathrm{p}>0.05)$. Bars under the mean values represent standard deviations. 


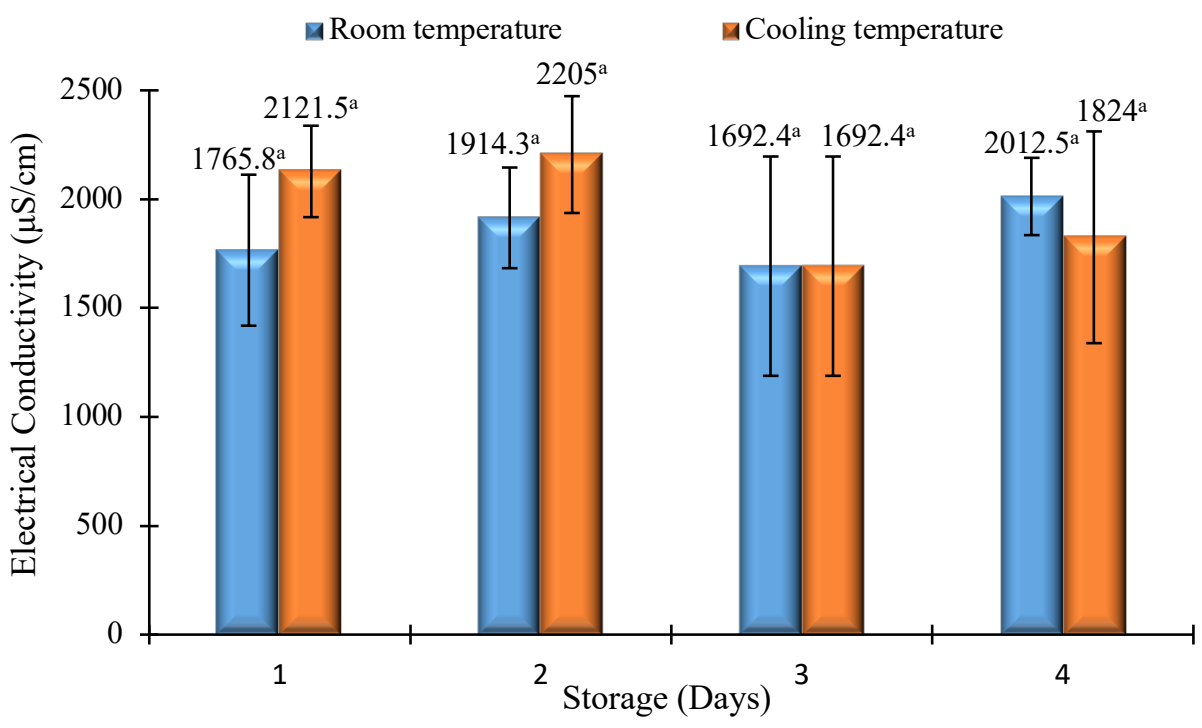

Fig.7. Changes in electrical conductivity of "kounou" during storage at room and refrigerator temperatures for 4 days. Mean values ( $n=3$ repetitions) with the same superscript are not significantly different $(\mathrm{p}>0.05)$. Bars under the mean values represent standard deviations.

\section{H. Changes in Total Dissolved Solids}

Total dissolved solids are the quantity of mobile charged ions, such as minerals, salts or metals that are dissolved in a drink and when it comes to water quality, the fluctuation of total dissolved solids is recognized as a cause of consumer complaints (Devesa \& Dietrich, 2018). Fig. 8 shows evolution of this parameter during storage of "kounou" at both room and refrigerated temperatures. Even if total dissolved solids increased with storage time, no significant change $(p>0.05)$ was revealed during the storage of the samples at room and low temperatures. Initial values of 925.4 $\mathrm{mg} / \mathrm{L}$ and $1061.2 \mathrm{mg} / \mathrm{L}$ were observed for the samples kept for a day at room and cold temperatures, respectively. The highest values were noticed after 4 days of storage at room $(1002 \mathrm{mg} / \mathrm{L})$ and refrigerated $(1231.7 \mathrm{mg} / \mathrm{L})$ conditions. Irrespective of the storage time, "kounou" samples stored into the refrigerator had greater values of the dissolved solids than those kept at room temperature. This suggests that some dissolved solids contained in "kounou" are used as nutrients for microbial growth during the storage of the drink at room temperature (Narendranath \& Power, 2005).

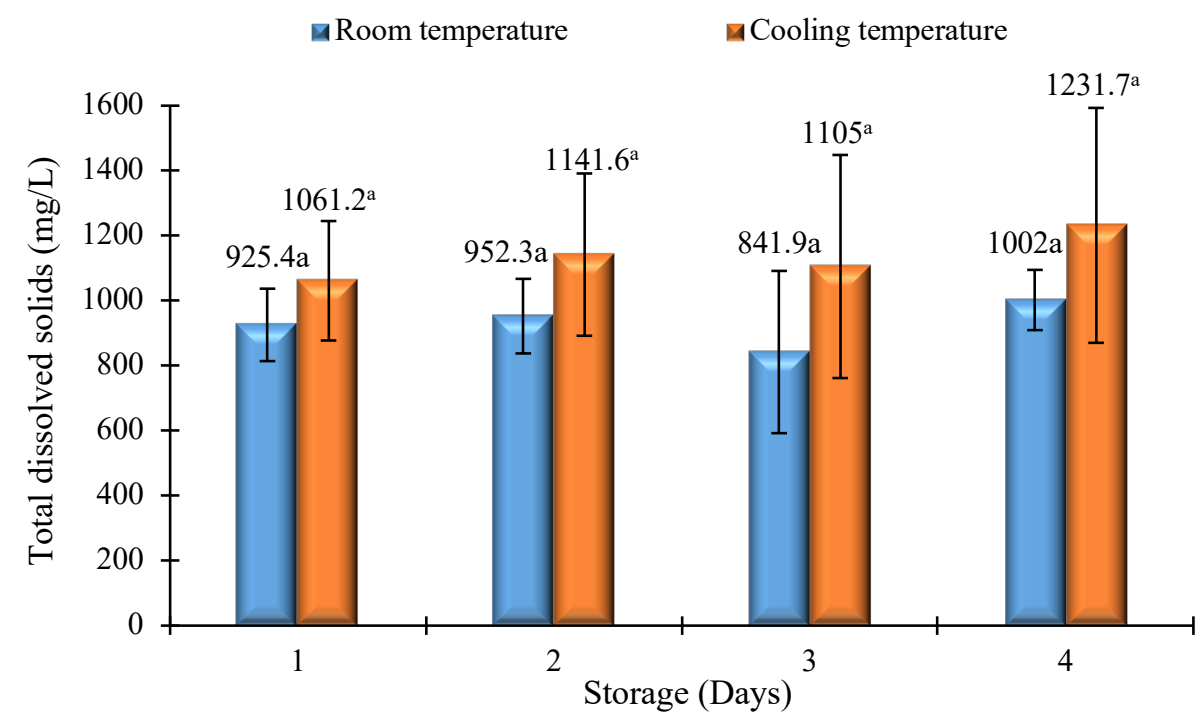

Fig.8. Evolution of total dissolved solids of "kounou" during storage for 4 days. Mean values (n= 3 repetitions) with the same superscript are not significantly different $(\mathrm{p}>0.05)$. Bars under the mean values represent standard deviations.

\section{Correlations Analysis}

The correlations between physicochemical parameters are presented in Table 1 . Total titratable acidity and $\mathrm{pH}$ were negatively correlated $(r=-0.931 ; p<0.001)$ which means that the production of organic acids was accompanied by a decrease in $\mathrm{pH}$ during the storage of "kounou" samples. A similar relation has been reported by Massieke et al. (2017) during the storage at room temperature of "zoom-koom", a fermented cereal-based beverage made in Burkina Faso. Meanwhile, $\mathrm{pH}$ was both significant and positively correlated to total sugar $(\mathrm{r}=0.907 ; \mathrm{p}<0.01)$, total soluble solids $(\mathrm{r}=0.849 ; \mathrm{p}<0.01)$ and dry matter $(\mathrm{r}=0.728 ; \mathrm{p}<0.05)$. Narendranath and Power (2005) reported a similar 
relationship between $\mathrm{pH}$ and soluble solids during ethanol production from Lactobacillus and Saccharomyces cerevisiae growth. Total titratable acidity and total sugar $(\mathrm{r}=-0.982 ; \mathrm{p}<0.001)$ were negatively correlated. This means that a decrease in sugar content of samples led to the production of organic acids during the storage. Therefore, fermentable sugars available in the beverage during storage are converted into organic acids by fermenting microorganisms. The same parameter was also negatively correlated to the total soluble solids $(r=-0.972 ; p<0.001)$ and dry matter $(r=-0.708 ; p<0.05)$ contents. This confirms the use of the soluble compounds during the microbial growth. A positive correlation was noted between dry matter and total dissolved solids $(\mathrm{r}=0.803 ; \mathrm{p}<0.05)$ on one side and dry matter and total soluble solids $(\mathrm{r}=0.761 ; \mathrm{p}<0.05)$ on another side. Total sugar and total soluble solids $(\mathrm{r}=0.972 ; \mathrm{p}<0.001)$ were highly correlated which means that sugar is one of the most soluble compounds present in "kounou" samples. Moreover, carbohydrates represent the major molecules that significantly accounted for the dry matter of "kounou" (Aka et al., 2014). Thus, a positive correlation has been noted between total sugar and dry matter $(\mathrm{r}=0.710 ; \mathrm{p}<0.05)$. A positive correlation was revealed between total soluble solids and alcohol content $(r=0.789$; $\mathrm{p}<0.05)$. This suggesting that the higher the soluble solid content of samples, the higher the alcohol content of the same samples during the storage. This result does not corroborate the previous report of Muyanja and Namugumya (2009). They found that increase in alcohol content corresponded to a decrease in total soluble solids during fermentation of Ugandan "kwete", a cereal-based beverage. The difference might be explained by the nature of the raw material and the traditional know-how used for the processing of both fermented cereal beverages. Sorghum is the main material used for the "kounou" production, while maize is the one used for the processing of "kwete". Even if the traditional processing of "kounou" and "kwete" is slightly similar, it is important to note that malt flour is added twice during the processing of "kounou" and once for the production of "kwete".

TABLE I: CORRELATION COEFFICIENTS BETWEEN PHySICOCHEMICAL DURING STORAGE OF «KOUNOU» BEVERAGE

\begin{tabular}{llllllll}
\hline \hline $\mathrm{pH}$ & TTA & TDS & TSS & TS & TA & DM & EC \\
\hline \hline 1 & & & & & & & \\
$-0.931^{\mathrm{z}}$ & 1 & & & & & & \\
0.502 & -0.592 & 1 & & & & & \\
$0.849^{\mathrm{y}}$ & $-0.972^{\mathrm{z}}$ & 0.696 & 1 & & & & \\
$0.907^{\mathrm{y}}$ & $-0.982^{\mathrm{z}}$ & 0.641 & $0.972^{\mathrm{z}}$ & 1 & & & \\
0.447 & -0.695 & 0.397 & $0.789^{\mathrm{x}}$ & 0.685 & 1 & & \\
$0.728^{\mathrm{x}}$ & $-0.708^{\mathrm{x}}$ & $0.803^{\mathrm{x}}$ & $0.761^{\mathrm{x}}$ & $0.710^{\mathrm{x}}$ & 0.382 & 1 & \\
0.450 & -0.385 & 0.341 & 0.273 & 0.423 & -0.106 & 0.138 & 1 \\
\hline \hline
\end{tabular}

$\left({ }^{\mathrm{x}}\right)$ : Correlation is statistically significant at $\mathrm{p}<0.05 .\left(^{\mathrm{y}}\right)$ : Correlation is statistically significant at $\mathrm{p}<0.01 .\left(^{\mathrm{z}}\right)$ : Correlation is statistically significant at $\mathrm{p}<0.001$. Notes: DM: Dry matter; EC: Electrical conductivity; TA: total alcohol; TDS: Total dissolved solids; TS: Total sugar; TSS: total soluble solids; TTA: total titratable acidity.

\section{J. Principal Component Analysis}

To investigate the interrelationships between the physicochemical properties and the design sample structuration during the storage, the principal component analysis (PCA) has been applied. The results have been reported in the biplot of Fig. 9. The PCA reduced the eight variables measured during the storage of "kounou" both at ambient and refrigerated temperatures in two main components (PC1 and PC2). Both components PC1 and PC2 described $83.6 \%$ of the total variation in the samples. Irrespective of temperature conditions during the storage of samples, seven of the eight measured physicochemical parameters were loaded to the main component PC1. Therefore, this component accounted for $66.3 \%$ of the total variance and was positively correlated to $\mathrm{pH}$, total dissolved and soluble solids, total sugar, total alcohol and dry matter. While, total titratable acidity was the only parameter negatively loaded to PC1. The second main component which accounted for $17.3 \%$ only describes electrical conductivity. It has been noticed from the same figure that the samples stored at different conditions were different, this means that we had two main clusters, one for the samples stored at ambient temperature and another for those kept under refrigeration. Inside the samples stored at the same thermal condition, some differences have been also found. The samples stored under refrigeration for 1 and 2 days were scored in the space defined by the positive sides of PC1 and PC2 axis. Given that they were so close, they can be grouped into the same sub cluster. Those kept for 3 and 4 days under refrigeration were scored in the dimension defined by the positive side of PC1 and the negative part of PC2. As they were closed, they can be both included in the same sub cluster. At room temperature, the samples stored for 1 and 4 days were very different. They were found in the negative side of PC1 and the space formed by the negative side of PC1 and the positive part of PC2, respectively. The samples stored at room temperature for 2 and 3 days were scored in the dimension formed by the negative side of both components PC1 and PC2. With regards to their proximity, the samples stored under refrigeration for 2 and 3 days have been included in the same sub-cluster. While, those kept at room temperature for 1 and 4 days were put into two separated sub clusters. 


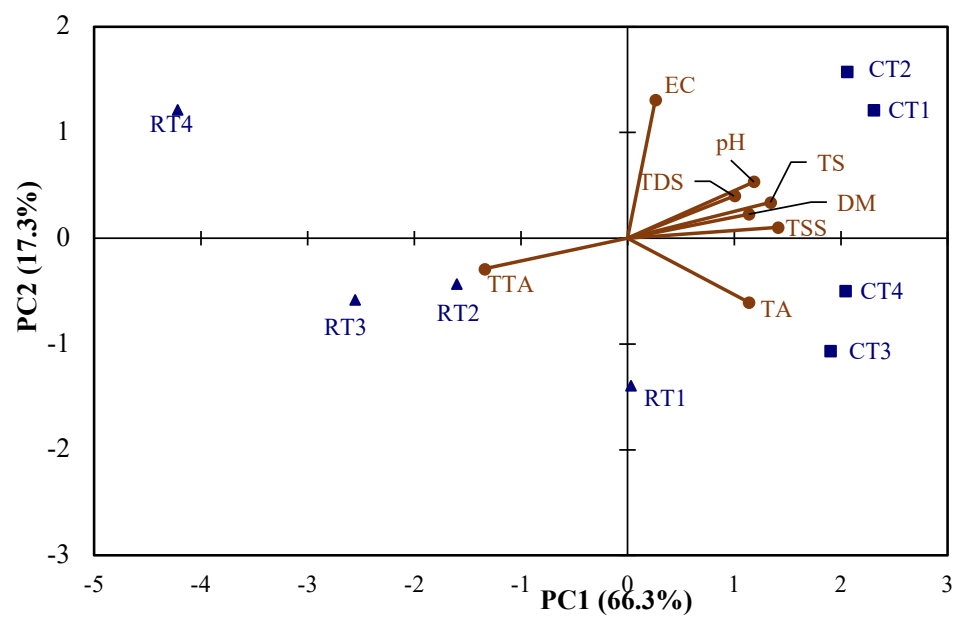

Fig. 9. Biplot from principal component analysis (PCA) after varimax rotation and Kaizer normalization $(p<0.05)$ of the "kounou" samples stored at room and cooling temperatures for 4 days. DM: Dry matter; EC: Electrical conductivity; TA: total alcohol; TDS: Total dissolved solids; TS: Total sugar; TSS: total soluble solids; TTA: total titratable acidity. Squares represent samples stored under refrigeration (CT). Triangles refer to samples stored at room temperature (RT).

\section{CONCLUSION}

In this study, the physicochemical changes during a shortterm storage of the marketed "kounou" were assessed at room temperature $\left(28 \pm 2^{\circ} \mathrm{C}\right)$ and under refrigeration $\left(4 \pm 1^{\circ} \mathrm{C}\right)$. These changes are not significant under refrigeration condition. Total soluble solids, $\mathrm{pH}$, and total sugar of "kounou" samples decrease and reach lower levels for those stored at room temperature than the ones kept under refrigeration. Total titratable acidity increases gradually, and the samples stored at room temperature present the highest values. At the end of the storage, the total acidity of the samples stored at ambient condition is 1.5 times higher than that of the samples maintained at low temperature. The alcohol content of "kounou" decreases during storage at room temperature, while it increases from the third and fourth day of storage under refrigeration. One unit of difference of the alcohol content has been noticed between the samples stored at room temperature and those kept under refrigeration for 4 days. There is no uniformity in changes of parameters like electrical conductivity, total dissolved solids and dry matter. Therefore, they might not be suitable markers to judge the stability of "kounou" during the storage. According to the parameters as total acidity and total sugar, it would seem that commercial "kounou" loss its stability after two days at room temperature, while at refrigerated temperatures "kounou" appears steady up to the end of storage. Therefore, as producers are low incomes and cannot afford the cost of refrigeration, they are constrained to produce the beverage daily. Given the importance of the homemade fermented cereal-based beverages in people's nutritional, social, and economic lives, and the fact that insufficient quality parameters have been used to characterize the stability of "kounou" at this level of study, more research is needed to develop appropriate preservative strategies that might improve the quality and extend the shelf life of this indigenous beverage made in Northern Cameroon. Moreover, sensory analysis would be necessary to evaluate the impact of the preservative methods on the acceptance of the beverage.

\section{ACKNOWLEDGMENT}

The authors are very grateful to Mr Yonas and Mr Yaya for their relevant support during the formal analysis.

\section{FUNDING}

This study has not received any specific funding either from public nor commercial agencies.

\section{CONFLICT OF INTEREST}

Authors declare that they do not have any conflict of interest.

\section{REFERENCES}

Abiodun, O. A., Dauda, A. O., Adebisi, T. T., \& Alonge, C. D. (2017). Physico-chemical, microbial and sensory properties of kunu zaki beverage sweetened with black velvet tamarind (Dialium guineense). Croatian journal of food science and technology, 9(1), 4656.

Adinsi, L., Mestres, C., Akissoé, N., Vieira-Dalodé, G., Anihouvi, V., Durand, N., \& Hounhouigan, D. J. (2017). Comprehensive quality and potential hazards of gowe, a malted and fermented cereal beverage from West Africa. A diagnostic for a future re-engineering. Food Control, 82, 18-25.

Aka, S., Konan, G., Fokou, G., Dje, K. M., \& Bonfoh, B. (2014). Review on African traditional cereal beverages. American Journal of Research Communication, 2(5), 103-153.

Alves-Araújo, C., Pacheco, A., Almeida, M. J., Spencer-Martins, I., Leão, C., \& Sousa, M. J. (2007). Sugar utilization patterns and respirofermentative metabolism in the baker's yeast Torulaspora delbrueckii. Microbiology, 153(3), 898-904.

Attchelouwa, C. K., Aka-Gbézo, S., N'guessan, F. K., Kouakou, C. A., \& Djè, M. K. (2017). Biochemical and microbiological changes during the Ivorian sorghum beer deterioration at different storage temperatures. Beverages, 3(3), 43.

Bayoï, J. R., Darman, D. R., \& Etoa, F. X. (2016). Technologie de fabrication, propriétés physico-chimiques et microbiologiques de la bière «kapsiki blanche» produite dans les monts Mandara au NordCameroun. Afrique Sciences, 12(6), 123-134. French.

Bayoï, J. R., Ndegoue, S. V., \& Etoa, F. X. (2021). Traditional processing and quality attributes of "kounou", a fermented indigenous cereal-based beverage from the northern zone of Cameroon. Journal of Agriculture and Food Research, 6, 100209. 
Binitu Worku, B., Gemede, H. F., \& Woldegiorgis, A. Z. (2018). Nutritional and alcoholic contents of cheka: A traditional fermented beverage in Southwestern Ethiopia. Food science \& nutrition, 6(8), 2466-2472.

Blandino, A., Al-Aseeri, M. E., Pandiella, S. S., Cantero, D., \& Webb, C. (2003). Cereal-based fermented foods and beverages. Food research international, 36(6), 527-543.

Blessed, K. Y., Dadah, A. J., \& Uba, A. (2017). Isolation of Enteric Bacteria from Hawked "Kunun-Zaki" in Chikun Local Government Area of Kaduna State. American Journal of Laboratory Medicine, 2(5), 96-98.

Coffin, R. H., Yada, R. Y., Parkin, K. L., Grodzinski, B., \& Stanley, D. W. (1987). Effect of low temperature storage on sugar concentrations and chip color of certain processing potato cultivars and selections. Journal of Food Science, 52(3), 639-645.

De Roos, J., \& De Vuyst, L. (2018). Acetic acid bacteria in fermented foods and beverages. Current opinion in biotechnology, 49, 115-119.

Debebe, A., Temesgen, S., Redi-Abshiro, M., Chandravanshi, B. S., \& Ele, E. (2018). Improvement in analytical methods for determination of sugars in fermented alcoholic beverages. Journal of analytical methods in chemistry, 2018, Article ID 4010298.

Devesa, R., \& Dietrich, A. M. (2018). Guidance for optimizing drinking water taste by adjusting mineralization as measured by total dissolved solids (TDS). Desalination, 439, 147-154

Duche, T. R., \& Abdulganiu, S. (2020). Growth Kinetics of Lactic Acid Bacteria in Kunun-Zaki Supplemented with Soymilk. International Journal of Current Microbiology and Applied Sciences, 9(7), 583-592.

Ebbah, L., Laryea, D., Barimah, J., \& Djameh, C. (2015). Effect of steeping temperature on the quality of malt and Pito (an indigenous Ghanaian drink). Journal of the Institute of Brewing, 121(4), 518-523.

Egue, L. A., N'guessan, F. K., Aka-Gbezo, S., Bouatenin, J. P. K., \& Koussemon-Camara, M. (2018). Candida species in tchapalo and bangui, two traditional alcoholic beverages from Côte d'Ivoire. Fungal biology, 122(5), 283-292.

Ezekiel, C. N., Abia, W. A., Ogara, I. M., Sulyok, M., Warth, B., \& Krska, R. (2015). Fate of mycotoxins in two popular traditional cereal-based beverages (kunu-zaki and pito) from rural Nigeria. LWT-Food Science and Technology, 60(1), 137-141.

Ezekiel, C. N., Ayeni, K. I., Ezeokoli, O. T., Sulyok, M., Van Wyk, D. A., Oyedele, O. A., et al. (2019). High-throughput sequence analyses of bacterial communities and multi-mycotoxin profiling during processing of different formulations of Kunu, a traditional fermented beverage. Frontiers in microbiology, 9, 3282.

Ezekiel, C. N., Ayeni, K. I., Misihairabgwi, J. M., Somorin, Y. M., ChibuzorOnyema, I. E., Oyedele, O. A., et al. (2018). Traditionally processed beverages in Africa: a review of the mycotoxin occurrence patterns and exposure assessment. Comprehensive Reviews in Food Science and Food Safety, 17(2), 334-351.

Fadahunsi, I. F., Ogunbanwo, S. T., \& Fawole, A. O. (2013). Microbiological and nutritional assessment of burukutu and pito (indigenously fermented alcoholic beverages in West Africa) during storage. Natural Science, 11(4), 98-103.

Fellows, P., Adinsi, L., Vieira-Dalode, G., Akissoé, N., Anihouvi, V., Mestres, C., et al. (2014). Processing and quality attributes of gowe: A malted and fermented cereal-based beverage from Benin. Food Chain, 4(2), 171-183.

Ferone, M., Ercole, A., Raganati, F., Olivieri, G., Salatino, P., \& Marzocchella, A. (2019). Efficient succinic acid production from highsugar-content beverages by Actinobacillus succinogenes. Biotechnology progress, 35(5), e2863.

Ghosh, K., Maity, C., Adak, A., Halder, S. K., Jana, A., Das, A., et al. (2014). Ethnic preparation of haria, a rice-based fermented beverage, in the province of lateritic West Bengal, India. Ethnobotany Research and Applications, 12, 039-049.

Guillamón, J. M., \& Mas, A. (2009). Acetic Acid Bacteria-Biology of Microorganisms on Grapes, In Must and in Wine, Springer International Publishing, Swiss, pp. 43-64.

Hounhouigan, D.J. (1994). Fermentation of maize (Zea mays L.) meal for mawe production in Benin: physical, chemical and microbiological aspects. [Ph.D dissertation, Wageningen Agricultural University, Wageningen, Netherlands].

Huang, L., Hwang, A., \& Phillips, J. (2011). Effect of temperature on microbial growth rate-mathematical analysis: the Arrhenius and Eyring-Polanyi connections. Journal of food science, 76(8), E553E560.

Kayode, A. P. P., Vieira-Dalodé, G., Kotchoni, S. O., Linnemann, A. R., Hounhouigan, J. D., Van Boekel, M. A. J. S., \& Nout, M. J. R. (2011). Diversity of yeasts involved in the fermentation of tchoukoutou, an opaque sorghum beer from Benin. African Journal of Microbiology Research, 5(18), 2737-2742.
Maduka, N., \& Ire, F. S. (2017). Effect of storage temperature on the nutritional compositions of lactic acid bacteria fermented spicy tigernut-milk drink. Int J Biochem Res Rev, 18(4), 1-13.

Magrí, A. D., Magrí, A. L., Balestrieri, F., Sacchini, A., \& Marini, D. (1997). Spectrophotometric micro-method for the determination of ethanol in commercial beverages. Fresenius' journal of analytical chemistry, 357(7), 985-988.

Massieke, A. A. R. S., Tapsoba, F. W. B., Kabore, D., Seogo, I., Tankoano, A., Dicko, M. H., et al. (2017). Etude sur la capacité de production, du circuit de commercialisation et de la consommation du zoom-koom vendu dans la ville de Ouagadougou au Burkina Faso. International Journal of Biological and Chemical Sciences, 11(5), 2294-2305. French.

Mathieu, B., Zenabou, G., Hamadou, L., Alim, A. Y. Y., \& Amadou, N. M. (2021). Caractérisation de l'artisanat agro-alimentaire de la ville de Garoua (Nord, Cameroun). Journal of Applied Biosciences, 159, 16429-16437. French.

Mugula, J. K., Nnko, S. A. M., Narvhus, J. A., \& Sørhaug, T. (2003). Microbiological and fermentation characteristics of togwa, a Tanzanian fermented food. International journal of food microbiology, 80(3), 187-199.

Muyanja, C. M. B. K., Narvhus, J. A., Treimo, J., \& Langsrud, T. (2003). Isolation, characterisation and identification of lactic acid bacteria from bushera: a Ugandan traditional fermented beverage. International journal of food microbiology, 80(3), 201-210.

Muyanja, C., \& Namugumya, B. S. (2009). Traditional processing, microbiological, physiochemical and sensory characteristics of kwete, a Ugandan fermented maize-based beverage. African Journal of Food, Agriculture, Nutrition and Development, 9(4), 1046-1059.

Muyanja, C., Birungi, S., Ahimbisibwe, M., Semanda, J., \& Namugumya, B. S. (2010). Traditional processing, microbial and physicochemical changes during fermentation of malwa. African Journal of Food, Agriculture, Nutrition and Development, 10(10), 4124-4138.

Narendranath, N. V., \& Power, R. (2005). Relationship between pH and medium dissolved solids in terms of growth and metabolism of lactobacilli and Saccharomyces cerevisiae during ethanol production. Applied and environmental microbiology,71(5), 22392243.

Noah, A. A., Rukayat, A. O., \& Foluso, F. (2013). Microbiological, physicochemical and sensory assessment of improved Kunun-Zaki beverage made from Millet and stored under different storage conditions. International Journal of Food Safety, Nutrition, Public Health and Technology, 5(2), 8-13.

Ortolan, F., Hecktheuer, L. H., \& de Miranda, M. Z. (2010). Effect of storage at low temperature $\left(-4^{\circ} \mathrm{C}\right)$ in the color and acidity content of wheat flour. Ciência e Tecnologia de Alimentos, 30(1), 55-59.

Price, P. B., \& Sowers, T. (2004). Temperature dependence of metabolic rates for microbial growth, maintenance, and survival. Proceedings of the National Academy of Sciences, 101(13), 4631-4636.

Pswarayi, F., \& Gänzle, M. G. (2019). Composition and origin of the fermentation microbiota of mahewu, a Zimbabwean fermented cereal beverage. Applied and environmental microbiology, 85(11), e0313018.

Ronald, B. J., \& Roger, D. D. (2017). Traditional processing and quality control of the "red kapsiki": a local sorghum beer from northern Cameroon. Brewing Technology, 6(3), 159-160.

Tamang, J. P., \& Nikkuni, S. (1998). Effect of temperatures during pure culture fermentation of Kinema. World Journal of Microbiology and Biotechnology, 14(6), 847-850.

Temilade, O. P., Festus, F. I., \& Oluwabunmi, A. A. (2020). Physicochemical, Microbiologically Nutritional and Sensory Evaluation of Ogi (A Traditonal Cereal Based Beverage in Nigeria) Produced from Two Varieties of Sorghum. The International Journal of Biotechnology, 9(1), 38-49.

Tusekwa, T.C.E., Mosha, H.S., Laswai, E.E., \& Towo, A. B. (2000). Traditional alcoholic beverages of Tanzania: production, quality and changes in quality attributes during storage. International journal of food sciences and nutrition, 51(2), 135-143.

Yakushi, T., \& Matsushita, K. (2010). Alcohol dehydrogenase of acetic acid bacteria: structure, mode of action, and applications in biotechnology. Applied microbiology and biotechnology, 86(5), 12571265.

Yeğin, S., \& Üren, A. (2008). Biogenic amine content of boza: A traditional cereal-based, fermented Turkish beverage. Food Chemistry, 111(4), 983-987.

Zwietering, M. H., De Koos, J. T., Hasenack, B. E., De Witt, J. C., \& Van't Riet, K. (1991). Modeling of bacterial growth as a function of temperature. Applied and environmental microbiology, 57(4), 10941101. 